\title{
Changes of coal rank and petrographic composition of coals from the drillhole BD 57 deposit of "Bzie-Dębina" in the Jastrzębie area (SW part of the Upper Silesian Coal Basin)
}

\author{
Krystian Probierz, Marta Kwaśny \\ Silesian University of Technology, Faculty of Mining and Geology, Institute of Applied Geology; ul. Akademicka 2, \\ 44-100 Gliwice; e-mail: krystian.probierz@polsl.pl,marta.kwasny@polsl.pl \\ (C) 2014 Authors. This is an open access publication, which can be used, distributed and reproduced in any medium according \\ to the Creative Commons CC-BY 4.0 License requiring that the original work has been properly cited.
}

\begin{abstract}
The aim of the work was to characterize in coalification parameters (moisture content $W^{a}$, volatile matter $V^{\text {daf }}$ and random reflectance of vitrinite $R$ ) and changes in petrographical composition of coal from the Bzie Dębina drillhole (BD 57). The object of examination were representative coal seams from the BD 57 drillhole. It was found increase of coal rank is expressed by a reduction of moisture content and volatile matter and the increase reflectance with depth. In petrographic composition vitrinite group macerals $\left(\mathrm{Vt}^{\mathrm{mmf}}=65.8-91.0 \%\right)$ dominate over the inertinite group $\left(\mathrm{I}^{\mathrm{mmf}}=6.2-28.4\right)$. Participatiof liptinite maceral group is low $\left(\mathrm{L}^{\mathrm{mmf}}=1.9-5.8 \%\right)$. Inertinite macerals group participation does not increase with coal rank, unlike in the Zofiówka monocline.
\end{abstract}

Keywords: Upper Silesian Coal Basin, coal rank, vitrinite reflectance, coal petrography

\section{INTRODUCTION}

The BD 57 drillhole is located within the coking coal deposit of "Bzie-Dębina" on the Jastrzębie area (SW part of the Upper Silesian Coal Basin). This area with coal deposits is significant for the resource base of Polish coking coal because Poland belongs to the largest producers of coke worldwide (the position among the first ten countries) and is one of the top exporters of coke both in Poland and the world. The largest producer of the highest quality coke is Jastrzębska Spółka Węglowa SA (Jastrzębie Coking Coal Company - JSW SA). The activity and development of JSW SA is significant for the economics of Poland. For a keeping the extraction of coking coal on high level and increase the resource base, the company began in 2007 to work providing new coking coal deposit - "Bzie-Dębina 2-Zachód". In the next few years (from about 2017) there will begin exploitation of coking coal from the new deposit.

The new exploitation field and in fact a new mine should be characterized by the best possible recognition of coal quality and its variability in the deposit, particularly that coking coals of the Zofiówka monocline are distinguished by significant variability of quality and coalification (Gabzdyl \& Probierz 1986, Gabzdyl 1989, Probierz \& Komorek 1994, Probierz et al. 2006, 2012). A similar situation is possible in the new field "Bzie-Dębina 2-Zachód", situated in the direct neighborhood of the monocline. Good recognition of the deposit facilitates economic and safe extraction. 
Metamorphism of the coal in Upper Silesian Coal Basin is described by the ability of the reflectance of vitrinite $(R)$, decrease of the content of volatile matter $\left(V^{\text {daf }}\right)$ and moisture $\left(W^{a}\right)$ according to the depth (i.a. Kotas et al. 1983, 1994, Gabzdyl 1989, Sivek et al. 2008, 2010, Probierz et al. 2012). Among these parameters the most significant for the characteristics of coal rank and estimation of coal quality is the vitrinite reflectance $R$, being the only and independent (from petrographic composition) indicator of metamorphism (Stach et al. 1982, Gabzdyl 1989, Taylor et al. 1998, Sivek et al. 2008, Probierz \& Marcisz 2009, 2010, Probierz et al. 2012).

In the coal mines of the Jastrzębie area, in order to recognize the variability of coal, there are usually determined indicators of technical analysis, elemental composition and coking properties, in accordance with the Polish Standard. Petrographic composition and optical indicators devotes receives much less attention, which often results in an inaccurate characterization of coal quality (Gabzdyl \& Probierz 1986, Probierz \& Komorek 1994, Probierz et al. 2012).

Thus, vitrinite reflectance $R$ is essential for the industrial value of coal, allowing for accurate determination of coal rank and the analysis of the reflectogram is useful for example during the distinguishing of homogenous coals from coal mixtures (Probierz \& Marcisz 2009, 2010, Probierz et al. 2012). The petrographic composition influences also the industrial value. The interpretation of results is based on the division of petrographic compounds into reactive, non-reactive and compounds with catalytical influence. Macerals of the vitrinite and liptinite groups are considered as reactive, it means they are able for sintering, and non-reactive are the macerals of the group of inertinite (Gabzdyl 1989, Probierz et al. 2012). The characteristics of reflectance and petrographic composition of coal in the new "Bzie-Dębina" mine can be considered pioneering for the deposit because in JSW SA there is no such data.

\section{STUDY AREA}

The drillhole Bzie Dębina 57 (Fig. 1) is situated in the southern part of the Silesia voivodship, on the terrain of the Jastrzębie Zdrój commune, in locality Bzie and in the region of "Bzie-Dębina 2-Zachód” coal deposit. Coal deposit of "Bzie-Dębina" is located in the south-west part of the main basin of the Upper Silesian Coal Basin, between the two regional faults (Bzie-Czechowice and Fault III), with throw to $800 \mathrm{~m}$. In the north and the north-west of the study area is located the Jastrzębie fault.

In the lithostratigraphic profile of the study area occured Upper Carboniferous strata covered by Neogen (Miocene) and Quaternary sediments of variable thickness.

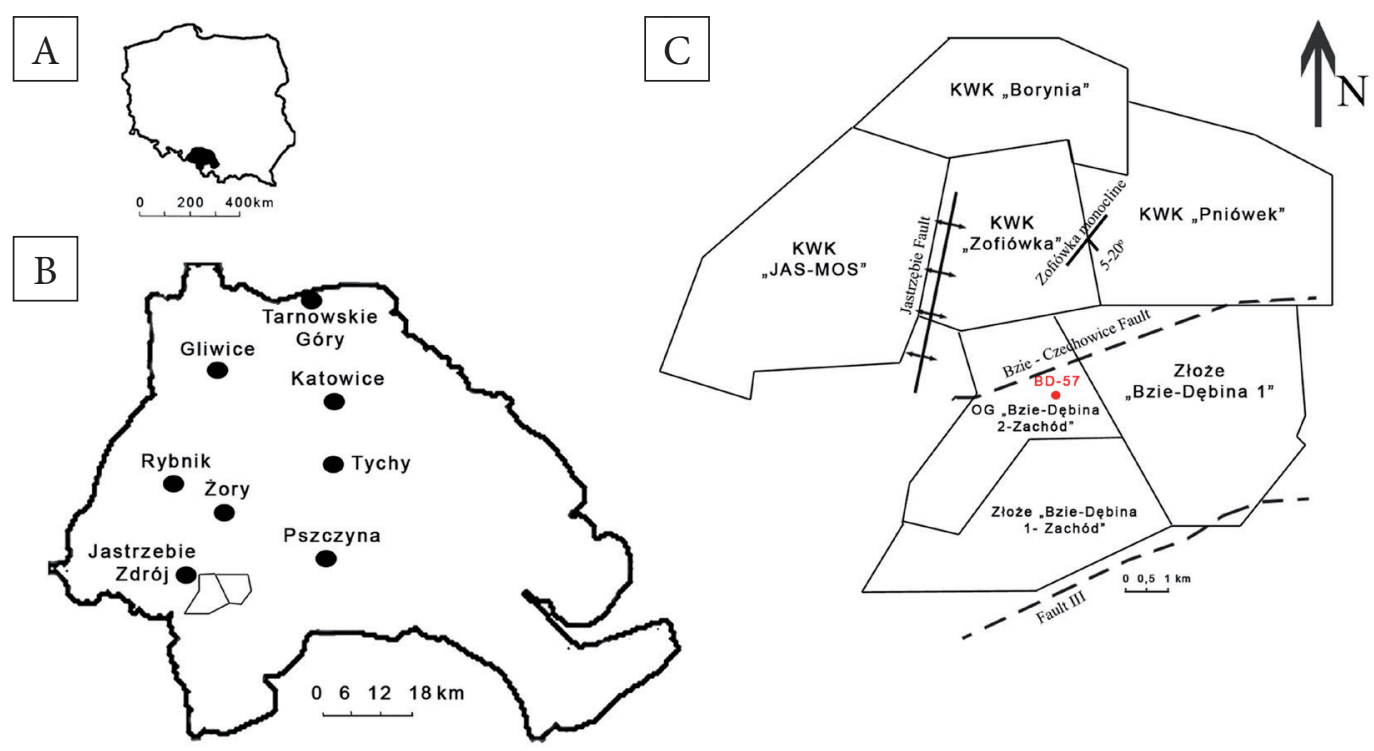

Fig. 1. Location of the drillhole Bzie Dębina 57: A) Upper Silesian Basin against the Poland; B) "Bzie-Dębina" area against Upper Silesian Coal Basin; C) BD 57 drillhole location 
Upper Carboniferous strata is presented by Upper Paralic Series (Poręba Beds), Upper Silesian Sandstone Series (Zabrze Beds and Ruda Beds) and Siltstone Series (Załęże Beds) (Kotas et al. 1983, Martinec et al. 2005, Probierz et al. 2012, Sivek et al. 2010). The results presented in this paper include Lower and Upper Załęże Beds.

The first documentary evidence of the "Bzie-Dębina" deposit was done in 1978. The second time the part of this coal deposit, "Bzie-Dębina 1-Zachód”, was documented in the year 2004 (Fig. 1). The drilling of the BD 57 drillhole started on $30^{\text {th }}$ July 2007. The aim was conducting of investigations and describing characteristics of hydrogeological, geological-engineering and gas conditions for the purposes of drilling the "1 Bzie" shaft. The drillhole was drilled in the layers from the Quaternary (till the depth $26.0 \mathrm{~m}$ ), through the Tertiary (till the depth $745.1 \mathrm{~m}$ ) till the depth $1163.0 \mathrm{~m}$ in Załęże Beds of the Carboniferous (from the seam 358 to 407/2). In the drillhole there were drilled 21 seams and the drilling was finished on $26^{\text {th }}$ March 2008.

\section{METHODS}

The research conducted in the laboratory of Applied Geology Institute Silesian University of Technology is based on data from core samples obtained from BD 57 drillhole, drilled by the company Przedsiębiorstwo Robót Geologiczno-Wiertniczych Sp. z o. o. The results of research were done with using the reflected light microscope Axioskop made by ZEISS with a microphotometer. There was applied immersion with coefficient of light refraction $n_{0}=1.5176$ in the temperature $297 \mathrm{~K}$ by the length of light wave $546 \mathrm{~nm}$. The measurements were done in the polarized light. The microscopic pellets were prepared as briquettes.

For examination there were chosen samples of 9 from 21 seams drilled in the drillhole BD 57. The selected seams are representative because they occur in the whole area (or on the largest part of the terrain), they are foreseen for the exploitation regarding thickness and resources of coal as well as they represent possibly all parts of the lithostratigraphic profile.

The results both technical analysis and vitrinite reflectance are presented on the background of simplified geological profile of drillhole BD 57. The results of petrographic composition are presented as a chart of particular groups of macerals in the analyzed seams.

\section{RESULTS}

The variability of coal rank in the drillhole BD 57 indicates distinct increasing tendency within depth (Tab. 1).

Table 1.

Coalification parameters and pethrographic composition in coal seam

\begin{tabular}{|c|c|c|c|c|c|c|c|c|c|c|c|c|}
\hline \multirow[t]{2}{*}{$\begin{array}{c}\text { Seam } \\
\text { number }\end{array}$} & \multirow[t]{2}{*}{$\begin{array}{c}\text { Depth } \\
\text { [MBGL] }\end{array}$} & \multicolumn{2}{|c|}{$\begin{array}{c}\text { Coalification } \\
\text { parameters } \\
{[\%]}\end{array}$} & \multicolumn{2}{|c|}{$\begin{array}{c}\text { Optical } \\
\text { parameters } \\
{[\%]}\end{array}$} & \multicolumn{7}{|c|}{$\begin{array}{c}\text { Petrographic composition } \\
{[\%]}\end{array}$} \\
\hline & & $W^{a}$ & $V^{\text {daf }}$ & $R$ & $\boldsymbol{s}$ & Vt & $\mathbf{L}$ & I & SM & $\mathrm{Vt}^{\mathrm{mmf}}$ & $\mathbf{L}^{\mathrm{mmf}}$ & $\mathrm{I}^{\mathrm{mmf}}$ \\
\hline 358 & -827.6 & 1.5 & 31.6 & 0.88 & 0.05 & 74.3 & 5.0 & 9.2 & 11.5 & 84.0 & 5.6 & 10.4 \\
\hline $362 / 2$ & -930.6 & 1.4 & 31.2 & 0.91 & 0.03 & 82.1 & 2.5 & 5.6 & 9.8 & 91.0 & 2.8 & 6.2 \\
\hline $403 / 1$ & -988.5 & 1.2 & 28.5 & 0.98 & 0.05 & 42.8 & 3.8 & 18.5 & 34.9 & 65.8 & 5.8 & 28.4 \\
\hline $403 / 2$ & -1003.2 & 1.0 & 27.2 & 0.99 & 0.04 & 67.7 & 4.2 & 27.6 & 0.5 & 68.1 & 4.2 & 27.7 \\
\hline $404 / 2$ & -1032.0 & 1.1 & 28.3 & 1.02 & 0.05 & 66.9 & 4.5 & 16.5 & 12.1 & 76.1 & 5.1 & 18.8 \\
\hline $404 / 4$ & -1053.0 & 1.1 & 27.6 & 1.03 & 0.04 & 67.1 & 1.6 & 16.6 & 14.7 & 78.7 & 1.9 & 19.4 \\
\hline $405 / 1$ & -1071.8 & 1.3 & 27.1 & 1.04 & 0.04 & 77.6 & 2.3 & 9.4 & 10.7 & 86.9 & 2.6 & 10.5 \\
\hline $406 / 1$ & -1099.5 & 1.0 & 27.6 & 1.08 & 0.05 & 71.4 & 4.0 & 17.0 & 7.6 & 77.3 & 4.3 & 18.4 \\
\hline $406 / 2$ & -1120.7 & 1.1 & 26.0 & 1.25 & 0.07 & 46.0 & 1.2 & 9.9 & 42.9 & 80.6 & 2.1 & 17.3 \\
\hline
\end{tabular}




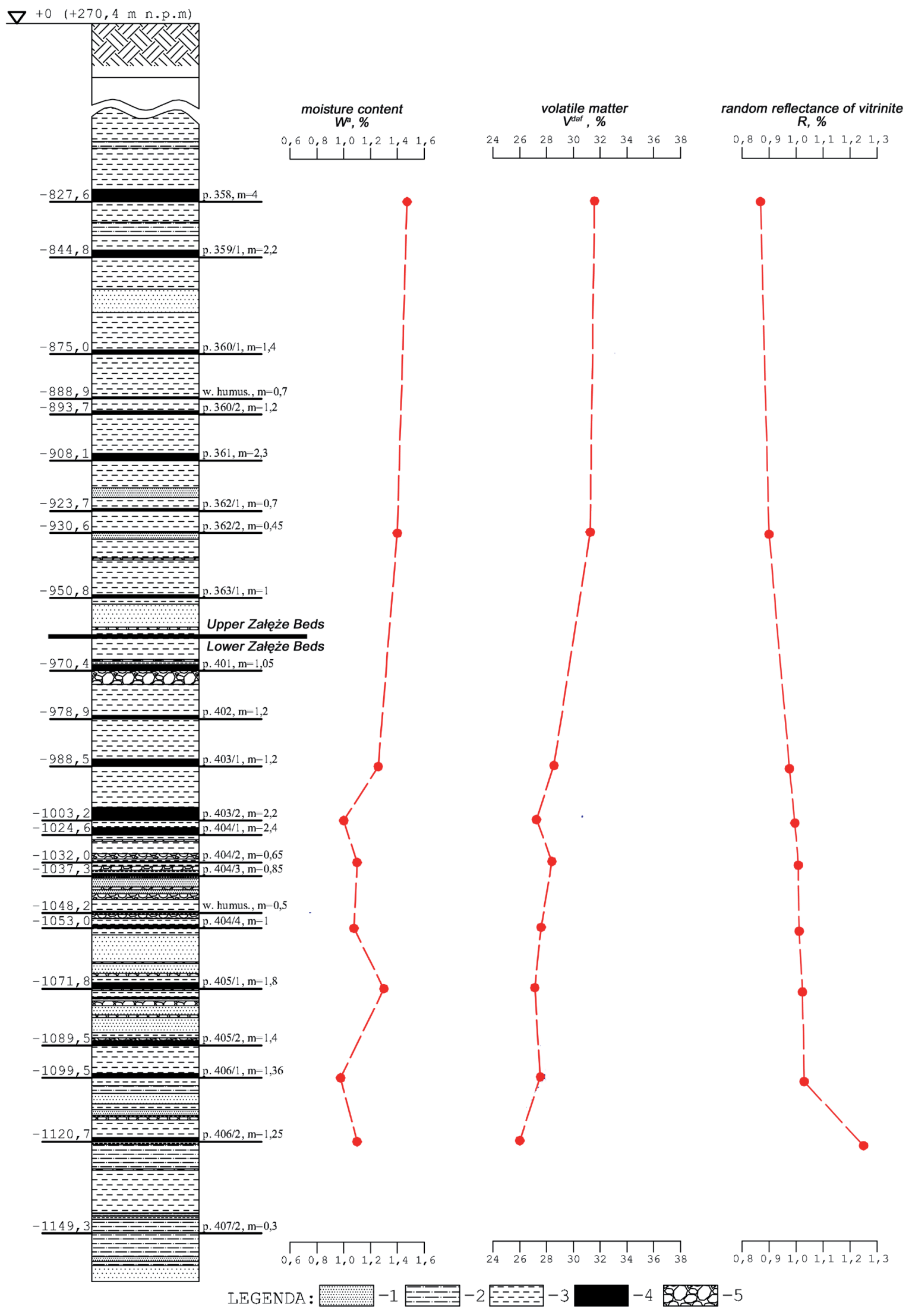

Fig. 2. Moisture content $W^{a}$, volatile matter $V^{\mathrm{daf}}$ and random reflectance of vitrinite $R$ in the borehole BD 57: 1 - sandstone, 2 - siltstone, 3 - claystone, 4 - coal, 5 - breccia 
The moisture content $W^{a}$ in the profile of drillhole BD 57 shows decreasing tendency with increasing depth. The highest content of moisture reaches $1.5 \%$ in the seam 358 , and the lowest value $1.0 \%$ in the seam $406 / 1$. In the lower part of profile from the seam 403/1 till the seam 406/2 the moisture content has the variable character, alternate rises and diminishes, but generally here the Schürmann rule is observed - moisture content decrease with depth (Fig. 2).

The volatile matter content $V^{\text {daf }}$ in the seams drilled in borehole BD 57 also decreases within the depth, reaching maximum equal to $31.6 \%$ in the seam 358 and minimum with a value $26.0 \%$ in the seam $406 / 2$. The trend of the changes is less pronounced, among the seams 358 and 362/2 the volatile matter content reaches value over $31.0 \%$, than decrease resulting in the range of $27.0-28.5 \%$ in the seams 403/1 till 406/1. In the seam 406/2 appears a sudden decrease of volatile matter till $26.0 \%$ (Fig. 2). The observations confirm occurrence in the analyzed drillhole the Hilt rule - the volatile matter decreases with depth.

The coal from drillhole BD 57 are characterized by mean random reflectance of vitrinite $R$ in the range from $0.88 \%$ in the seam 358 till $1.25 \%$ in the seam $406 / 2$ (increase with depth), by standard deviation $s=0.03-0.07$ (Tab. 1, Fig. 2). In nearly the whole depth profile among examined seams (one by one) there is observed little increase of reflectance (average of $0.01 \% R$ for ca. $20 \mathrm{~m}$ ), just in the last depth section between seams $406 / 1$ and 406/2 occurs a sudden increase of a parameter from $1.08 \%$ till $1.25 \%$ (increase of $0.17 \% R$ for ca. $20 \mathrm{~m}$ ).

The increase of vitrinite reflectance with the coalification increase confirms its connection with volatile matter content $V^{\text {daf }}$ (Fig. 3). The values of reflectance $R$ correlate significantly with the values of volatile matter $V^{\text {daf }}$ in dependence reverse proportional. These relationships may be useful for the study area too.

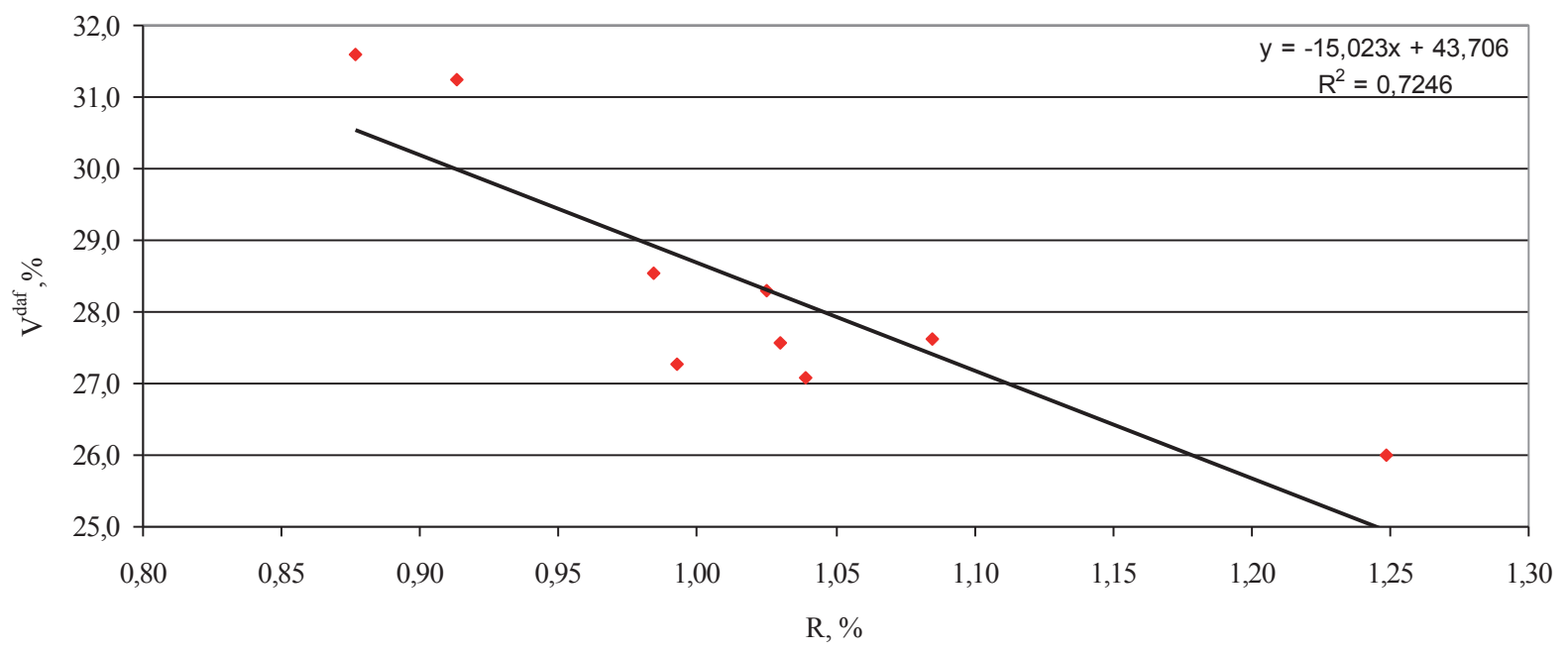

Fig. 3. Relationship between vitrinite reflectance and volatile matter content of analyzed coal seams in Zofiówka monocline by Probierz et al. 2006

In the petrographic composition of the coal from drillhole BD 57 there is observed a distinct domination of macerals of vitrinite group $\left(\mathrm{Vt}^{\mathrm{mmf}}=65.8-91.0 \%\right)$ over inertinite $\left(\mathrm{I}^{\mathrm{mmf}}=6.2-28.4 \%\right)($ Tab. 1). The highest content of vitrinite $\mathrm{Vt}^{\mathrm{mmf}}=90 \%$ occurs in the seam $362 / 2$, and the lowest $\mathrm{Vt}^{\mathrm{mmf}}=65.8 \%$ the seam $403 / 1$ (Fig. 4). The content of the macerals of group of vitrinite $\mathrm{Vt}^{\mathrm{mmf}}$ in examined seams does not prove the correlation with coal rank. The high content of vitrinite $\mathrm{Vt}^{\mathrm{mmf}}>80 \%$ are characterized coals with volatile matter content $V^{\mathrm{daf}} \sim 26.0-27.0 \%$ (seam $405 / 1$ and 406/2), as well as the coals with $V^{\text {daf }}>$ $31 \%$ (seam 358, 362/2). All the other coal samples with volatile matter content $V^{\text {daf }}=27.3-28.5 \%$ show lower vitrinite content (Fig. 4). A characteristic of the macerals from vitrinite group is occurrence (similarly as in other coals from Jastrzębie area) of telinite with visible cellular structure (Fig. 5). 


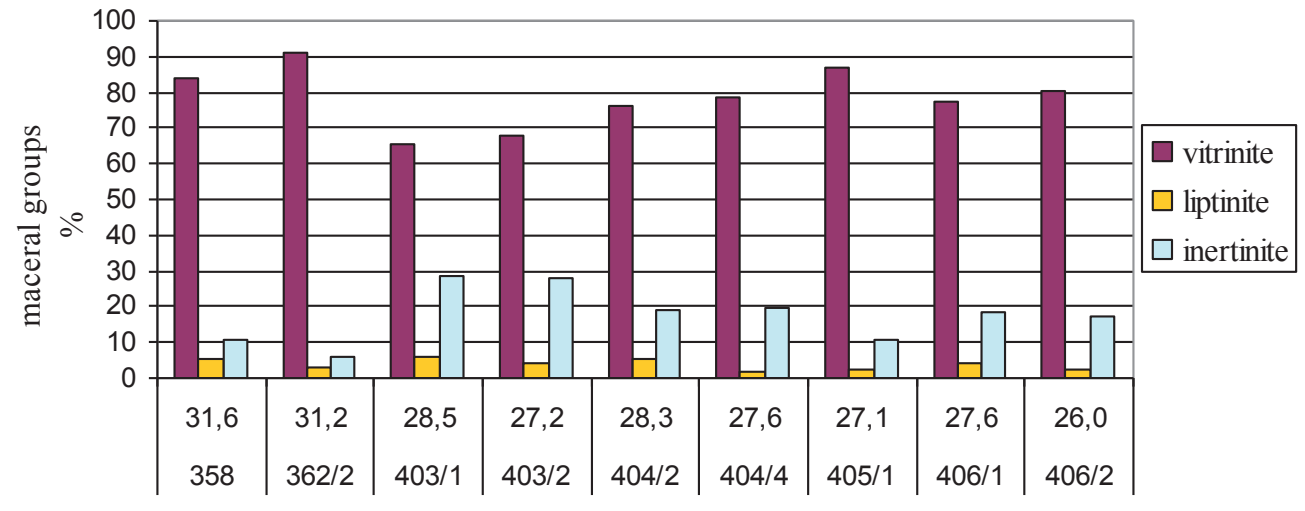

volatile matter content/seam number

Fig. 4. The share of individual groups of macerals of coal seams in borehole BD 57
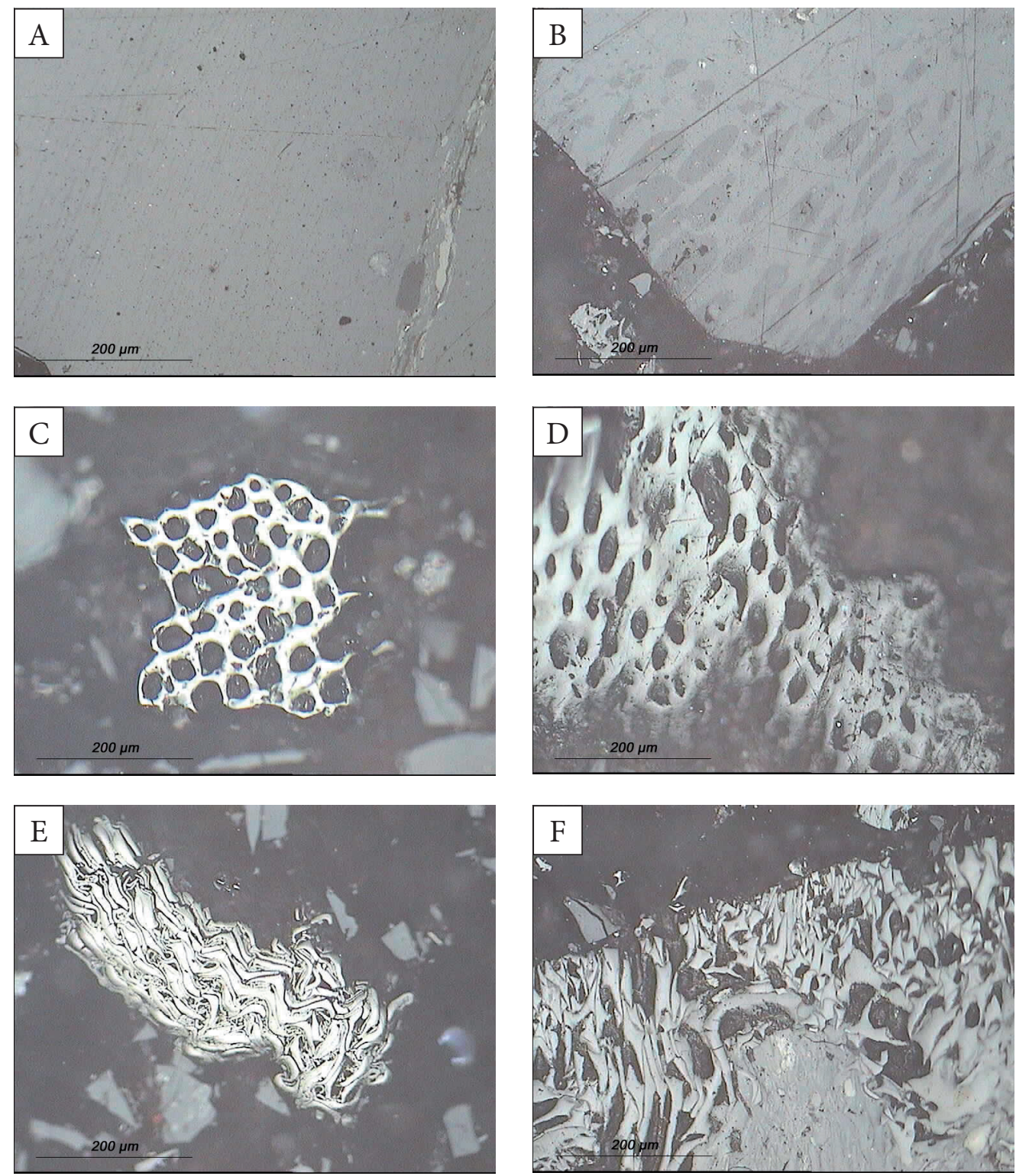

Fig. 5. Photomicrographs: A) vitrinite (collotelinite), seam 403/2; B) vitrinite (telinite which well - preserved cellular structure), seam 404/2; C) inertinite (fusinite), seam 406/1; D) inertinite (fusinite), seam 404/4; E) inertinite (semifusynite), seam 404/2; F) inertinite (semifusinite), seam 406/2 

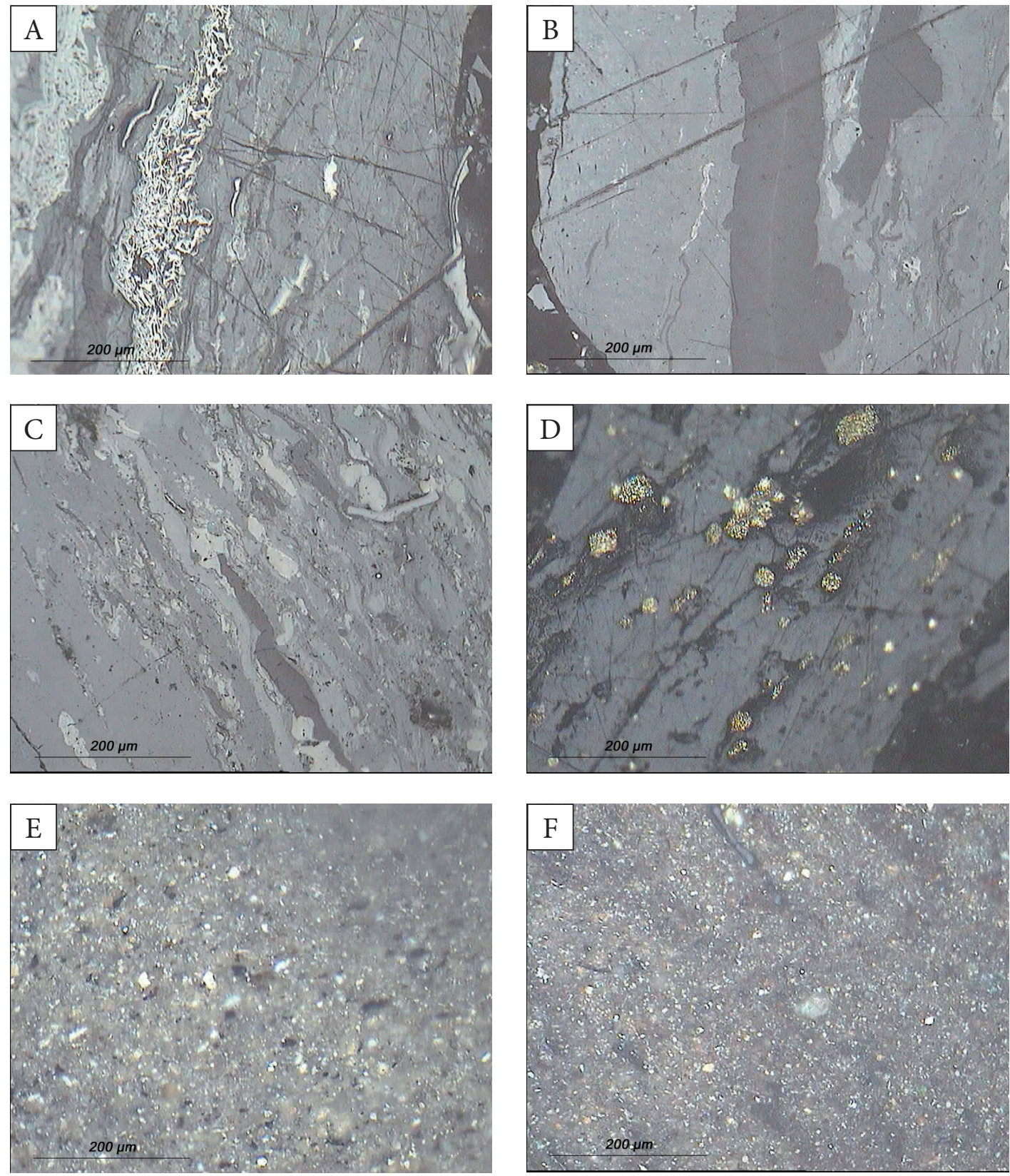

Fig. 6. Photomicrographs: A) vitrinite and inertinite, seam 362/2; B) liptinite (makrosporinite), seam 404/2; C) trimacerite, seam 404/2; D) framboidal form of pyrite, seam 362/2; E) mineral matter with pyrite, seam 403/2; F) dispersed mineral matter, seam $406 / 2$

The changes of macerals of inertinite group content $\left(\mathrm{I}^{\mathrm{mmf}}\right)$ proceed (what is logic) reversely to the changes of vitrinite content (within the increase of vitrinite decreases inertinite content). The highest content of inertinite $\mathrm{I}^{\mathrm{mmf}}=28.4 \%$ occurs in the seam 403/1, and the lowest inertinite $\mathrm{I}^{\mathrm{mmf}}$ content occurs seam $362 / 2\left(\mathrm{I}^{\mathrm{mmf}}=6.2 \%\right)$ (Tab. 1, Fig. 4).

The coals from the "Bzie-Dębina" area (examined only in the drillhole BD 57) do not show higher content of the discussed maceral group like other coal from Jastrzębie area. Additionally, there is no proved correlation between increase of macxeral percentage content (inertinite group) and coal rank what happened in the "Borynia-Zofiówka-Jastrzębie” Coal Mine (Probierz et al. 2012).

The participation of macerals of liptinite group is low $\left(\mathrm{L}^{\mathrm{mmf}}=1.9-5.8 \%\right)$. The highest participation of macerals of liptinite group is characterized the seam $358\left(\mathrm{~L}^{\mathrm{mmf}}=5.6\right)$, whereas the lowest 
- in the 404/4seam $\left(\mathrm{L}^{\mathrm{mmf}}=1.9\right)($ Tab. 1, Fig. 4). The mineral substance participation in the observed samples changes in the range from $0.5 \%$ in the seam 403/2 till $42.9 \%$ in the seam $406 / 2$ (Tab. 1). Petrographic compounds of investigated coal are presented on Figures 5 and 6 .

\section{CONCLUSIONS}

Conducted research showed a distinct tendency of increase of coal rank with depth described by the decrease of moisture content $W^{a}$ and volatile matter $V^{\text {daf }}$ and increase of reflectance $R$. The change of moisture content in the depth profile indicates occurrence of Schürmann's rule, in the drillhole BD 57, but decrease of volatile matter confirms the Hilt's rule.

The described coals represent humus coal medium coal rank (ortobituminous $\mathrm{C}$ and metabituminous $\mathrm{B}: R=0.88-1.25 \%)$ with purity degree in the range from medium to high $\left(A^{d}=7.0-11.4 \%\right)$ (International Classification of Seam Coals 1995).

In the BD 57 drillhole there is no anomaly coalification in the form inversion, as was in the "Moszczenica" and "Borynia-Zofiówka-Jastrzębie" mine in the vicinity of the drillhole (Gabzdyl \& Probierz 1987, Probierz 1989, Probierz et al. 2012).

In the petrographic composition the largest participation have macerals of vitrinite group $\left(\mathrm{Vt}^{\mathrm{mmf}}=65.8-91.0 \%\right)$. Among them occurs telinite with good preserved cellular structure, which was also found in the other coals from Jastrzębie area. Coals from the Jastrzębie area described by numerous authors are characterized by significant participation of macerals from inertinite group what is not observed in the coals from the drillhole $\mathrm{BD} 57$, where inertinite content is in the range $\mathrm{I}^{\mathrm{mmf}}=6.2-28.4 \%$. There was not observed an increase of participation of inertinite proceeding with the increase of coalification what has taken place in the "Borynia-Zofiówka-Jastrzębie" Coal Mine (Probierz \& Komorek 1994, Probierz et al. 2006, 2012).

A lack of anomaly of coalification and low proportion of macerals of the inertinite group may be a reason of lack of influence of thermal metamorphism in "Bzie-Dębina" area (and certainly in BD 57) which influenced the coals of Zofiówka monocline and Jastrzębie area (Gabzdyl \& Probierz 1987, Probierz 1989). It seems that the regional Bzie-Czechowice fault with release reaching $700 \mathrm{~m}$ did not alter the degree of coalification coals from "Bzie-Dębina". This may suggest that the coalification was done before the creation of the deformation.

The presented results of investigations of coalification and pethrographic composition done in Załęże Beds as composed mainly of fineclastic sediments. In the analyzed profile predominate claystone and siltstone over the finegrainy sandstone. And the coal seams generally have an average thickness (1.5-3.0 m). Lithologically, analyzed sediments do not differ from the described in the vicinity (Probierz 1987). The coalification of the "Bzie-Dębina" area seems to be related to the impact regional metamorphism, the dominance of preorogenic phase (Stach et al. 1982, Kotas et al. 1993, Kotas 1994, Taylor et al. 1998). Pioneering studies of vitrinite reflectance and petrographic composition of coal from "Bzie-Dębina" area need to be supplemented by additional research. It would help to take a more explicit approach to the causes of coalification.

\section{REFERENCES}

Gabzdyl W., 1989. Geologia węgla. Skrypty Uczelniane Politechniki Ślaskiej, 1427, 2, Gliwice.

Gabzdyl W. \& Probierz K., 1986. Pozycja węgli z południowej części Rybnickiego Okręgu Węglowego (typy 34-42) w klasyfikacji genetyczno-przemysłowej. Zeszyty $\mathrm{Na}$ ukowe Politechniki Śląskiej, Górnictwo, 149, Gliwice.

Gabzdyl W. \& Probierz K., 1987. The occurrence of anthracites in an area characterized by lower rank coal in the Upper Silesian Coal Basin of Poland. International Journal of Coal Geology, 7, 209-225.

International Classification of Seam Coals, Final Version, 1995. Economic Commission for Europe, Committee on Energy, Working Party on Coal, Fifth session.

Kotas A. (red.), 1994. Coal-bed methane potential of Upper Silesian Coal Basin, Poland. Prace PIG, 142, Warszawa.

Kotas A., Buła Z., Gądek S., Kwarciński J. \& Malicki R., 1983. Geological Atlas of the Upper Silesian Coal Basin. Part 2: Coal Quality Maps. Wydawnictwa Geologiczne, Warszawa.

Martinec P., Jirasek J., Kozusnikova A. \& Sivek M. (ed.), 2005. Atlas uhli česke časti hornoslezske panve. Anagram, Ostrava.

Probierz K., 1987. Zmienność jakości węgla w złożach kopalń: „Borynia”, „Manifest Lipcowy” i „XXX-lecia PRL” (ROW) na tle budowy petrograficznej pokładów. Zeszyty Naukowe Politechniki Śląskiej, Górnictwo, 140, Gliwice. 
Probierz K., 1989. Wpływ metamorfizmu termalnego na stopień uwęglenia i skład petrograficzny pokładów węgla w rejonie Jastrzębia (GZW). Zeszyty Naukowe Politechniki Ślaskiej, Górnictwo, 176, Gliwice [postdoctoral thesis].

Probierz K. \& Komorek J., 1994. Zmienność jakości węgli pokładów warstw załęskich monokliny Zofiówki. XVIII Sympozjum Geologiczna formacja węglonośna Polski, Wydawnictwa AGH, Kraków, 114-117.

Probierz K. \& Marcisz M., 2009. Szacowanie jakości węgla w złożu według Polskiej Normy i Międzynarodowego Systemu Kodyfikacji Węgla z użyciem programów Surfer i AutoCAD. Przegląd Górniczy, 65, 3-4, 19-24.

Probierz K. \& Marcisz M., 2010. Estimation of the hard coal quality in deposit In view of national and international standards. Archives of Mining Sciences, 55, 4, 847863.

Probierz K., Komorek J. \& Lewandowska M., 2006. Charakterystyka zmian składu petrograficznego węgla z KWK „Zofiówka”. Górnictwo i Geologia, 3, 1, 67-79.
Probierz K., Marcisz M. \& Sobolewski A., 2012. Od torfu do wegli koksowych monokliny Zofiówki w obszarze Jastrzębia (południowo-zachodnia część Górnoślaskiego Zagłębia Węglowego). Wydawnictwo Instytutu Chemicznej Przeróbki Węgla, Zabrze.

Sivek M., Čáslavský M. \& Jirásek J., 2008. Applicability of Hilt's law to the Czech part of the Upper Silesian Coal Basin (Czech Republic). International Journal of Coal Geology, 73, 2, 185-195.

Sivek M., Jirásek J., Sedláčková L. \& Čáslavský M., 2010. Variation of moisture content of the bituminous coal with depth: A case study from the Czech part of the Upper Silesian Coal Basin. International Journal of Coal Geology, 84, 1, 16-24.

Stach E., Mackowsky M.T., Teichmüller M.R., Taylor G.H. \& Chandra D., 1982. Stach's Textbook of Coal Petrology. Gebrüder Borntraeger, Berlin-Stuttgart.

Taylor G.H., Teichmüller M., Davis A., Diessel C.F.K., Littke R. \& Robert S., 1998. Organic Petrolog. Gebrüder Borntraeger, Berlin-Stuttgart. 